\title{
Internationalization, Deregulation and the Expansion of Higher Education in Korea: An Historical Overview
}

\author{
Christopher Green ${ }^{1}$ \\ ${ }^{1}$ Melbourne Graduate School of Education, The University of Melbourne, Parkville, VIC, 3010, Australia \\ Correspondence: Christopher Green, Melbourne Graduate School of Education, The University of Melbourne, \\ Parkville, VIC, 3010, Australia. Email: greencr22@gmail.com
}

Received: April 5, 2015

Accepted: April 22, 2015

Online Published: April 28, 2015

doi:10.5430/ijhe.v4n3p1

URL: http://dx.doi.org/10.5430/ijhe.v4n3p1

\begin{abstract}
The purpose of this article is to provide an overview of internationalization policies in Korean higher education since 1993. Deregulation was a key strategy of Korean governments, but this strategy has led to an increasing oversupply of enrolment capacity. In response, the current government is implementing a system of reregulation to reduce the number of institutions and control admission quotas. Although cross-national comparisons put Korea's schooling system among the world's highest performing, deep structural and cultural challenges exist in higher education. The article recommends that future policy development and implementation should focus on three broad areas: 1) strengthening quality assurance; 2) increasing engagement with international bodies and networks; and 3) enforcing regulatory compliance.
\end{abstract}

Keywords: Internationalization policies, Deregulation, Quality, Higher education, Korea

\section{Introduction}

\subsection{The Korean Experience as a National Case Study}

Over the last two decades, national governments have adopted policies to promote the internationalization of their higher education systems (Note 1) through greater student, faculty and institutional mobility. Internationalization is not seen as an end in itself, but as an enabling characteristic to build national economic competitiveness. Economic rationales increasingly inform internationalization policies (Knight, 2004). Universities in particular, are seen as portals of globalization and are being encouraged by national governments to broaden their international reach and provide countries with cultural, economic, and technological competitiveness to meet the wider challenges of globalization (Bauman, 2014). Korea is no exception, and since the early 1990s, governments have vigorously pursued reforms to internationalize the higher education system (Byun \& Kim, 2011; Kwon, 2012; Shin, 2015b). In turn, Korean higher education institutions (HEIs) (Note 2) have implemented a range of internationalization strategies at the program level.

Elected as a civilian president in 1992, after a period of military authoritarian government, Kim Young Sam introduced his signature suite of segyehwa (Note 3) policies to broaden Korea's successful economic globalization into social and cultural areas. A key element of segyehwa in the higher education sector was a systematic shift to market-based policies designed to invigorate the sector and draw in private resources to fund expansion of service delivery. A long tradition of centralized control made way for deregulation and corporatization. Private HEIs outside of the Seoul area were allowed to determine student quotas and regulations to establish new institutions were relaxed. This led to the proliferation of new institutions and the rapid increase of enrolment capacity. However, a simultaneous decline in the birthrate led to a decrease in the number of high school graduates flowing into higher education and a corresponding decline in enrolment projections. This, in turn, forced the government to implement difficult policies to reduce the number of HEIs, particularly small, private institutions, and to reduce quotas for new students.

Korea's economic growth is relatively well examined, and this article locates higher education policies within that national developmental story. Shin (2015) points out that the phenomenon of rapid economic growth across East Asia is driving the shift from elite higher education to mass higher education. This shift has produced complex challenges shared by countries in the region including: "decoupling of research and teaching, quality of education, privatization 
and cost sharing, managerialism and academic freedom, and over-education and unemployment" (2015, p. 2). The Korean experience of internationalization policies engages with all of these issues, yet within a specific national narrative. While the impact of these polices has been substantial, the data shows that only limited progress has been made towards internationalization goals. This article will not only contribute to knowledge of national policy making in Korea, but also to a broader understanding of the internationalization of national higher education systems (Note 4).

\subsection{Internationalization: the conceptual terrain}

Universities have long been considered among society's most international institutions and cross border interaction between academics has been evident over many centuries (Teichler, 2007). This article, however, focusses on quite recent patterns of mobility in higher education. Knight defines the internationalization of higher education as "the process of integrating an international, intercultural or global dimension into the purpose, functions or delivery of post-secondary education" (2004, p. 11). She also articulates the important terminological distinction that internationalization can be considered a response to globalization. While globalization involves the flow of technology, economy, knowledge, people, values and ideas across borders, "internationalisation of higher education is one of the ways a country responds to the impact of globalisation yet, at the same time respects the individuality of the nation" (Knight, 1997, p. 6).

The first wave of internationalization in higher education primarily occurred at the elite university level in advanced countries and involved the movement of students, exchange of academic faculty, internationalized curricula and networking arrangements with other elite institutions (Findlay, 2010). However, the literature describes a new wave of internationalization that is now shared by many more universities in many more countries. Van der Wende notes that "internationalisation is becoming an important dimension in higher education policy and developed at the institutional level, related to the challenges of globalisation, which increasingly affect the higher education sector" (2001, p. 251). Student and faculty mobility is increasing rapidly, programs of study and institutions themselves regularly operate across borders, joint degree programs, off-shore campuses and distance learning programs are now commonplace and international research collaboration is an expected feature of academic work (Findlay, 2010).

Fee paying international students provide a major source of export revenue which has created significant financial interests in higher education as a service sector industry. There were 2.1 million students studying across borders in 2000, which more than doubled to 4.5 million in 2012 and that number is predicted to rise to 7 million in 2020 (OECD, 2014). This raises the debate about the commodification of higher education as internationalization is increasingly driven by economic goals (Altbach, 2004). The General Agreement on Trade in Services (GATS) was established in 1995 in order to advance the rules-based nature of the trade in services. Education, including higher education, is included within the GATS. (Note 5) As the World Trade Organisation (WTO) observed at the time, the economic rationale calling for services liberalisation under GATS, is no different in principle from the rationale that has driven the liberalisation of mechandise trade under GATT since 1948 (WTO, 2001).

\subsection{Internationalization Indicators}

This article focusses on national policies and macro outcomes, however, the broad indicators used to measure internationalization necessarily include activity at the institutional level. The five indicators used here are:

1. International ranking tables of national higher education systems. The article uses two separate annual tables: The Global Competitiveness Report; and Universitas 21. The former includes an indicator that measures quality of higher education (WEF indicator 5.03), which is included in the Korean Ministry of Education's (MOE) annual reporting. The latter is a research institute that ranks national higher education systems using 24 measures across four categories to create an annual ranking table of 50 countries.

2. International ranking tables of higher education institutions. The article uses two separate tables: The Times Higher Education World University Ranking (The Times Ranking), and the Quacquarelli Symonds World University Ranking (QS). While the value of these ranking tables provokes fierce disagreement among educators, the tables do provide a source of quantitative data on core higher education activities. The Times Ranking criterion called 'international outlook' comprises four sub-measures: international research collaboration; ratio of international to domestic students; ratio of international to domestic faculty; and research journal publications that have at least one international co-author. The Times Ranking also annually publishes The Times Asia Ranking. QS, also UK based, includes three internationalization sub-measures: numbers of inbound and outbound exchange students; international student support, for example religious facilities; and international diversity. QS also publishes an annual QS Asia list 
3. Level of international research collaboration and research productivity. This indicator addresses quality of research which strongly influences the reputation of national systems. It is often measured by the number of research articles published in international journals listed in the three major indices: Science Citation Index (SCI), Social Sciences Citation Index (SSCI), and the Arts and Humanities Citation Index (AHCI). These influence Korean government funding for HEIs. This indicator also influences HEI status, which in turn influences demand for enrolments and the recruitment of competent faculty.

4. Number of foreign students and faculty. (Note 6) This indicator addresses the capacity of national systems to capture a share of the escalating demand for international higher education services, build an international workforce and create an international environment within its institutions.

5. Quality of English medium instruction (EMI) programs. Language of instruction is a key driver of student mobility (OECD, 2014). The dominance of English speaking countries as host destinations has been most effectively challenged in the last decade by those non-English speaking countries, particularly in Europe, that have high quality English language teaching and English in the institutional environment.

\section{Higher Education in Korea}

\subsection{The Historical Setting}

Higher learning institutions for Confucian scholars have a long history in Korea, but higher education in its modern form only emerged in the twentieth century. The first two institutions, Daehak and Gyungdang, were founded in 372AD. In 1398, Sungkyunkwan was established and still operates as Sungkyunkwan University. These first institutions were "based on the three traditional principles of Confucian education - virtue, civility and excellence and focused on subjects like the study of nature, household management, country governance, and ideals such as sincerity, morality and universal harmony" (OECD, 2009, p. 19). In pre-modern Korea, prestigious civil service jobs were open to those who passed the Sino-influenced national exams. Koreans thus still regard higher education as a means to an enhanced socio-economic position (Chang, 2007). Confucian philosophy stresses learning and scholarship, which in turn influences social status. A clear hierarchical relationship exists between teachers and students. This view still persists to some extent in modern Korea, and influences teaching style, organizational culture and administrative processes within Korean HEIs.

Kyungsung Imperial University, the predecessor of Seoul National University (SNU), was the first modern university established during Japanese colonial rule. It derived its founding principles from the Humboldtian tradition of the pursuit of knowledge which sat easily with pre-existing Confucian mores and created a cultural environment in which universities operated with relative autonomy (Byun, 2008). On top of Confucian and European influences, US influence after World War Two, including the large number of US educated faculty added another layer to the culture of the modern Korean higher education system. Byun argues that this history underpins a tension between a 'cultural' belief system emphasizing the disinterested pursuit of knowledge and a 'utilitarian' belief system that knowledge should be pursued to achieve social goals (2008).

World War Two ended Japanese colonial occupation and seven national universities were established to contribute to national economic reconstruction. Higher education policy was located within developmental goals and can be understood as an element of Korea's economic success within the Bretton Woods system. There is an extensive literature to describe the Korean 'developmental state' that engaged aggressively with the global economic system. (Note 7) Indeed, of the countries that have benefited most from economic globalization, the post-World War Two story of Korea's export-oriented, late industrialization stands out and is well documented.

After the Korean civil war (1950-53), a tightly controlled civil society participated in a highly regulated economic recovery that raised standards of living within a generation. Particularly after Park Chung Hee's military coup in 1961, there was strong regulation in all policy areas including higher education. HEIs were centrally regulated, enrolment numbers were centrally set and vocational education was encouraged to provide human resources for economic development (Kwon, 2012). Furthermore, as the economy grew, households accumulated enough wealth to pay tuition fees, and industry demand for more qualified personnel increased (Kim T., 2008).

After another coup in 1980, Chun Do Hwan introduced reforms to expand the sector and cater for this increasing demand. Whereas technological programs linked to economic development had been prioritized, the increase in enrolments from the 1980s was in the humanities and social sciences. During the 1980 s, there was a $30 \%$ increase in student numbers and Chun allowed some relaxation of government controls over HEIs in order to encourage expansion of private resources in the sector (Kim Y.C., 2008). Widespread social pressure for civil rights built through the 1980s leading to democratization. This period was a critical juncture for all policy making in Korea, 
including higher education policy. Byun points to the 'June 10 Democratization Movement' in 1987 as a key driver of participatory democracy and of the future policy reforms for Korean HEIs that were ahead (2013).

\subsection{Internationalization Policies since 1992 and Deregulation}

The election of Kim Young Sam in 1992 as the first civilian president in nearly 30 years drove further political liberalization including freedom of the press, greater freedoms of expression and assembly, the release of political prisoners, and the restoration of many civil rights. The Kim administration's approach to globalization quickly became much more strategic than previous governments. It expanded the globalization agenda into political, social and cultural policy areas. The economic value of cultural industries and the services sector, including higher education, came into sharper focus as potential drivers of exports, technological development and innovation (Yim, 2002). Higher education reforms were further incorporated into national economic objectives.

1995 was a critical turning point for Korean higher education. In that year, The Presidential Commission on Education Reform (PCER) launched the 31st May Plan (Note 8). The Plan further reduced central control over the establishment of private HEIs and student quotas which led to an increase in the number of small and medium sized private institutions in regional areas, as well as new graduate schools and online universities. The previously used 'permission' policy was replaced by the 'minimal conditions' policy for the establishment of new institutions (Kwon, 2012). Public universities, including national universities established by both the central and local governments however, were given less autonomy and regulation for public HEIs remained more pervasive. These policies were remarkably successful in expanding the higher education sector. Table 1 show that in 1990, there were 265 HEIs enrolling 1,691,681 students. By 2005, those figures had increased to 419 HEIs enrolling 3,548,728 students. At that point, however, the number of high school graduates flowing to higher education slowed and there were some initial closures and mergers of HEIs. In 2014, 3,668,747 students were enrolled in 433 HEIs that comprised: 189 universities, 139 junior colleges, 44 graduate schools, 17 cyber universities, 12 polytechnic colleges, 10 universities of education, 8 corporate HEIs, 2 industrial universities and 12 others (MOE, 2014).

Table 1. Growth in higher education in Korea, 1990 - 2014

\begin{tabular}{lcccccc}
\hline & 1990 & 1995 & 2000 & 2005 & 2010 & 2014 \\
\hline HEIs & 265 & 327 & 372 & 419 & 411 & 433 \\
Students & 1691681 & 2343894 & 3363549 & 3548728 & 3644158 & 3668747 \\
\hline
\end{tabular}

Source: Korean Ministry of Education, Statistical Yearbook of Education, 2014.

The $31^{\text {st }}$ May Plan also included specific internationalization goals for: student exchange; faculty exchange; inducements for foreign institutions, faculty and students; and policies for the export of Korean higher education services. Cho \& Palmer (2013) use primary sources to show that influential members of the government advocated strongly for an increase in the number of foreign professors and an increase in the level of EMI programs. One intention of EMI was to increase pressure on academic faculty to publish in English language scholarly journals which would, in turn, increase the competitiveness of Korean universities on global ranking tables (Kim Y. C., 2008).

The internationalization vision declared that universities were "the prime source of knowledge production and delivery and should be encouraged to be more market oriented and to link their development more closely to societal needs, most notably to the changing needs of the labor market" (Byung, 2008, p. 193). At the policy level, this was a clear statement of the government's expectations for universities to contribute to 'utilitarian' national development goals. The policy intention was to use internationalization to leverage change in university activity and outcomes (Choi, 2013). Political leaders also believed that strengthening Korea's elite universities would push them to become WCUs, benefit the country economically and bolster national pride.

In 1997, an exogenous shock further entrenched the deregulatory approach to higher education policy reform. The Asian Financial Crisis was caused by rapid growth funded by massive borrowings of international capital. Prices had inflated beyond their value leading to a sudden correction. Investment fled the region, currencies collapsed, economic output fell, unemployment increased and wages plummeted. A combination of bail-out packages was coordinated by the International Monetary Fund (IMF) for three East Asian countries: Indonesia, Korea and Thailand. Importantly, recovery loans were linked to immediate and rapid deregulation of capital markets, tariffs and financial governance. The notion that heavy regulation of HEIs should give way to a more autonomous and innovative sector became an important contextual feature of higher education reforms aimed at internationalization. 


\subsection{Major Policy Initiatives}

Since Kim Young Sam, consecutive governments with different ideological perspectives have all pursued the internationalization agenda through deregulation and as an element of wider economic liberalization. Table 2 shows the major initiatives and events since 1993 to illustrate that the scope and implementation of the policy agenda was designed to promote both internationalization and competitiveness in HEIs.

Table 2. Major Higher Education Policy Initiatives in Korea Since 1993

\begin{tabular}{|c|c|c|}
\hline Year & President & Major policy initiatives and events \\
\hline \multirow[t]{2}{*}{$1993-1998$} & Kim Young Sam & 1995, 31st May Plan \\
\hline & & Segyehwa, 1996 Korea joins OECD, 1997 Asian Financial Crisis \\
\hline \multirow[t]{2}{*}{$1998-2003$} & Kim Dae Jung & 1999-2005, BK21 Phase One (US\$1.2 billion) \\
\hline & & Consolidation of PCER reform goals \\
\hline \multirow[t]{6}{*}{$2003-2008$} & Roh Moo Hyun & 2006-2012, BK21, Phase Two (US\$2.3 billion) \\
\hline & & 2004, Study Korea Project \\
\hline & & 2004, University Restructuring Plan \\
\hline & & 2004-2008, New University for Regional Innovation (US $\$ 1.2$ billion) \\
\hline & & 2007, Vision for Internationalization of Higher Education \\
\hline & & 2007-2008, Quality assurance reforms \\
\hline \multirow[t]{4}{*}{$2008-2013$} & Lee Myung Bak & 2008-2012, World Class University Project \\
\hline & & 2009, Leading Industry Development Project for Economic Regions \\
\hline & & 2011, Disclosure of HEI evaluations \\
\hline & & HEI governance reforms, trade liberalization, FTAs \\
\hline \multirow[t]{4}{*}{$2013-(2018)$} & Park Geun Hye & 2013, Study Korea 2020 Project \\
\hline & & 2014, University for a Creative Korea \\
\hline & & Creative economy policy agenda \\
\hline & & Consolidation of institutional and program evaluations \\
\hline
\end{tabular}

Source: KEDI, 2011, KEDI, 2012, MOE, 2014.

Funding is central for policy leverage in all systems. In Korea, the low level of public spending is an important structural feature of higher education. In 2011, the government was responsible for only $27 \%$ of higher education spending, compared with the OECD average of $69.2 \%$. On the other hand, the ratio of private sector spending on higher education as a proportion of GDP was four times the OECD average (OECD, 2014). Therefore, initiatives with large budgets can be powerful tools of influence. Seven important initiatives with large budgets were:

1. 1999 - 2005, The Brain Korea 21 Program for Leading Universities and Students (BK21) was the largest single government funded initiative to address the perceived under-investment in higher education. It flowed directly from the government's response to the 1997 crisis as a means of using system wide reforms to connect research output with the wider economy. It included national targets, competitive funding rules, rewarded internationalization of research publications and articulated the goal of building world class universities as a national priority (Kwon, 2012).

2. 2004, The Study Korea Project aimed to recruit 50,000 foreign students by 2008. It was expanded in 2008 with a new target of 100,000 foreign students by 2012 (Byun, 2008). In 2013, the government again expanded the initiative into the Study Korea 2020 Project with a new target of 200,000 foreign students by 2020 . The 2020 Project also addresses quality assurance and recruitment policies (The Korea Times, 2012).

3. 2007, the Vision for the Internationalisation of Higher Education addressed the integration of higher education reforms into whole-of-government policy coordination across eleven ministries (Choi, 2013).

4. 2004-2008, the New University for Regional Innovation (NURI), introduced by Roh Moo Hyun, aimed to enhance regional innovation and distribute the benefits of the higher education system outside of Seoul.

5. 2008, the Lee Myung Bak administration launched the World Class University (WCU) project aimed at halting 
a perceived brain drain of Korean faculty abroad and to recruit highly qualified foreign faculty, with whom Korean universities and departments might enhance their international research output (Choi, 2013).

6. 2008, Lee Myung Bak also addressed sensitive governance reforms including the incorporation of national universities. The Seoul National University Incorporation Act, for example, was eventually passed in the National Assembly in 2010 after intense debate. These reforms to reduce central control over HEIs and allow them to plan more strategically were based directly on the experience in Japan, Malaysia and Singapore (Kwon, 2012).

7. 2009, Leading Economic Development Project for Economic Regions provided funding to HEIs outside of the metropolitan regions specifically aimed at align training with industry needs. The initiative included retraining opportunities in emerging industries for unemployed graduates (KEDI, 2011).

\subsection{Expansion, Overcapacity and Reregulation}

However, just as deregulation policies successfully encouraged the establishment of new private HEIs, the declining birthrate led to a decrease in the demand for higher education. As a result, Korean HEIs are facing the daunting reality of declining enrolment projections flowing from the declining number of high school graduates (KEDI, 2011). Table 3 shows that in 2005 there were 568,055 high school graduates, while the projection for 2025 declines to 402,769. On current admission quotas, this would result in a nationwide surplus of 197,215 HEI enrolment places. The problem of deceasing demand is exacerbated by the very high number of Korean students who go abroad. In 2011, 289,288 higher education students were studying abroad (MOE, 2014). On top of that, high graduate unemployment, lower graduate starting salaries and a generally weaker labor market persist as repercussions of the economic restructuring forced by the 1997 financial crisis. For the first time in contemporary Korea, this has raised questions among some families of high school graduates about the previously automatic decision to send school leavers directly to higher education. While Korea still has the highest enrolment rates in the OECD for higher education age groups, there has been a cultural shift.

Table 3. Decrease in High School Population and Surplus HEI Capacity in Korea, 2005 - 2025

\begin{tabular}{lccccc}
\hline & 2005 & 2010 & 2015 & 2020 & 2025 \\
\hline Final Year High School Population & 623855 & 679151 & 644695 & 508282 & 426311 \\
High School Graduates & 568055 & 641647 & 609094 & 480214 & 402769 \\
HEI Admission Quota & 636311 & 599984 & 599984 & 599984 & 599984 \\
Deficiency or (surplus) & $(68256)$ & 41663 & 9110 & $(119770)$ & $(197215)$ \\
\hline
\end{tabular}

Source: Statistics Korea 2010 cited in KEDI, 2011.

These forecasts have forced the government to implement a managed reregulation of HEIs. In December, 2004, the MOEHRD (Note 9) announced its University Restructuring Plan which detailed a rolling schedule of mergers and closures of smaller institutions. In 2005, eight regional, national HEIs were consolidated into four and 38 HEIs announced their intention to reduce enrolments by $10 \%$ over the next three years (Pillar and Cho, 2013). Table 3 shows that the government set admission quotas were reduced from 636,311 in 2005 to 599,984 in 2010. The University Restructuring Plan also detailed strategic initiatives including: specialization of existing institutions; incorporation of national universities; forming new university-industry links for regional economic development; and the liberalization of the domestic education market. Targets were to be achieved through financial incentives and penalties. For example, starting in 2006, private HEIs which exceeded a 40-1 student-faculty ratio were to be excluded from all government support (Kim T., 2008). Funding programs for HEIs and students are the main mechanism to enforce compliance with quality assurance in an overwhelmingly private system.

In 2011, a consultative committee was established to review the restructuring process and nominate HEIs, public and private, which would have admission quotas reduced. The Korean Council of University Education (KCUE) (Note 10) plays an important role on the restructuring committee given that its members, private HEIs, are being dramatically affected by this process. In 2013, the committee produced a revised plan that included a timetable to cut admission quotas in three stages. Firstly, quotas were reduced by 40,000 by 2016 . In the second stage, quotas will reduce by a further 50,000 between 2017 and 2019, and then a further 60,000 will be cut between 2020 and 2022 . Government funding for the bottom $15 \%$ of public universities will be cut completely. From 2015, the MOE will also rank HEIs according to a five tier scale and forcibly cut quotas in those HEIs rated in the second level and below 
(The Korea Times, 9 March, 2014). This may result in the closure of 30 to 50 HEIs over the next 10 years. KEDI forecast that, without this kind of major government intervention, up to 90 HEIs could have closed by 2030 (Sharma, 2011).

Legislative changes in 2007 and 2008 were designed to ensure that the restructuring process will be informed by a more rigorous quality assurance system. The new system has since been progressively introduced by the government and includes the KCUE as a key player (KEDI, 2011). Flowing from revisions to the Higher Education Act, the Government Recognition System for Evaluation and Accreditation includes elements of external evaluation and an electronic system of disclosure and dissemination of evaluation results. It will be an important driver of the restructuring process and replaced a much weaker evaluation system that was limited by a "lack of assessment mechanisms within universities, low levels of objectivity due to the non-disclosure of results, and the absence of incentives or sanctions that would motivate universities to participate in assessment activities (KEDI, 2011, p. 251).

The broad economic intentions of higher education reforms emphasizing competitive incentives for HEIs continue under the current Park Geun Hye administration. In 2014, for example, the government announced the University for a Creative Korea (CK) project that invests directly in specialized departments and programs to encourage specialization and innovation. Yet the structural tension between liberalization and overcapacity also continues. There has been much rhetoric and media enthusiasm for the Songdo International Business District, Incheon Global Campus, to attract international institutions. However, given the oversupply HEI capacity, convincing stakeholders to agree on regulatory structures for international institutions to enter the already declining higher education market has been slow. Large numbers of Korean students already choose to study abroad, indicating their preference for non-Korean degrees, so new competition from international universities within the country is clearly problematic. Given the declining Korean student market, only a handful of foreign universities have commenced operating including: The University of Utah, Stony Brook University, State University of New York, George Mason University and the University of Ghent (Korea Joonggang Daily, 29 September, 2014).

\section{Inside Korean HEIs: internationalization outcomes}

Internationalization has been taken up variously by Korean HEIs according to institutional capacity and conditions. However, outcomes against the indicators listed above are mixed. Also, there is a consensus in the literature that, while HEIs may have adopted the language of internationalization, this was, at least in part, driven by the need to comply with funding guidelines built into government priorities and to appeal to the declining student market which was seeking a 'global' education. Further, as a result of the unexpected explosion in HEIs and enrolment capacity, key stakeholders perceive a tension between the quantitative impacts of deregulation and qualitative outcomes on teaching and research (Cho \& Palmer, 2013).

\subsection{Indicator 1: National Ranking Tables}

In 2014, Universitas 21 ranked Korea 21st in its table of 50 national higher education systems. However, when relative levels of GDP per capita are taken into account Korea's overall ranking falls to 30th (Universitas 21, 2014). In 2014, The Global Competitiveness Report ranked Korea 73rd for quality of higher education system (WEF indicator 5.03), down from 57th in 2010 (WEF, 2014). These rankings not only provoke debate within Korea about higher education performance but also a wider discussion about the national approach to teaching and learning across other levels of education. While the OECD puts Korea at the top of international rankings for schooling education, according to student performance in tests such as the Programme for International Student Assessment (PISA), there is an ongoing concern about the level of 'soft skills' such as creativity, critical thinking, communication, and collaboration which are crucial for higher learning (OECD, 2009).

\subsection{Indicator 2: Institutional Ranking Tables}

Korea's elite universities have made modest gains in the closely observed annual institutional ranking tables over the last five years. According to The Times Ranking 2014, Korea has four universities in the top 200. In the 2014 QS ranking, Korea has six in the top 200. In the 2014 QS Asia, which is co-sponsored by the Chosun Ilbo, five Korean universities were in the top 20 in Asia. However, Korea has only 28 universities in the QS Asia top 200, down from 49 in 2013. For 25 of those 28, their ranking dropped on the previous year. These figures also point to a national 'ranking gap' emerging between elite universities and the majority of HEIs largely due to low scores in the field of academic reputation and the numbers of foreign faculty and students. (Chosun Ilbo, 17 September, 2014).

National debate in Korea is deeply influenced by these tables. However, policies driven by institutional ranking tables may not align with other important national interests. Focusing resources on a small number of elite universities in order to promote their position on the ranking tables may risk the quality of teaching and scholarship 
in the majority of institutions. HEIs are a key element of national human resource development and are expected to provide a national skills base. Further, access to higher education qualifications is crucial to citizens' opportunities and links graduates with needs in the labor market.

\subsection{Indicator 3: International Research Collaboration and Research Productivity}

As in other national systems, Korean HEIs reward international publications with appointments, promotion and tenure. Also, some postgraduate programs in Korea require publication as a condition of graduation for scholarship holders and as a preparation for future publications in English. Since the implementation of BK21, there have been dramatic increases in research productivity, according to this indicator (Shin, 2015). "During a period of just over a decade, the number of papers published in SCI journals by Korean scholars has almost quadrupled from 10,739 in 1998 to 39,843 in 2010" (Byun, Jon \& Kim, 2013, p. 652). This productivity is overwhelmingly located in the top five universities: SNU; Yonsei University; Korea University; the Korean Advanced Institute of Science and Technology (KAIST); and the Pohang University of Science and Technology (POSTECH).

There is, however, a growing gap between the disciplines in favor of science departments over social science and humanities. Science and technology projects accounted for $75 \%$ of all BK21 projects and $88 \%$ of WCU projects (Byun, Jon \& Kim, 2013). This influenced the location of research output and greatly affects the status and influence of the strongest departments in these disciplines within the top universities. This is also a reason why science and engineering dominate the distribution of government research funding. Notably, the Universitas 21 ranking for connectivity places Korea seventh out of 50 countries on joint publications with industry, but only 43rd on joint publications with international collaborators. Finally, some research areas are stronger, and The Times Asia 2014 identifies materials research as being well connected with the semiconductor industry as one example of successful alignment with industry.

\subsection{Indicator 4: Foreign Students and Faculty}

Recruitment of foreign students and faculty in all countries is greatly influenced by national performance and reputation. As discussed above, improvement in national performance is mixed and mainly located in relatively few elite HEIs. This partly explains why international student enrolments in Korea have increased in raw numbers but not as a percentage of total enrolments, even at a time when international student mobility is rapidly increasing, particularly in Asia. Shortcomings in recruitment strategies, lack of promotion, and poor management systems for international students are regularly criticized in the media. (The Korea Times, 28 September, 2013).

As shown in Table 4, in 1995 there were 1,983 foreign students representing $0.1 \%$ of total enrolments. In 2010, these numbers rose to 83,842 or $2.4 \%$ of total enrolments. In 2014 , the figures had changed little in spite of significant government activity and marketing effort by HEIs. Approximately $60 \%$ of foreign students received Korean government scholarships, over a quarter were enrolled only in language programs and around $90 \%$ came from Asia, mostly China (MOE, 2014). The Study Korea Project, which successfully recruited about 50,000 students by 2010, was credited for much of this increase (Choi, 2014). As mentioned above, the Study Korea 2020 Project has set a new target of 200,000 foreign students by 2020 .

Table 4. Foreign Students and Faculty in Korea, 1995 - 2014

\begin{tabular}{lccccc}
\hline & 1995 & 2000 & 2005 & 2010 & 2014 \\
\hline Number of Foreign Students & 1983 & 13832 & 22970 & 83842 & 84891 \\
Percentage of Total Students & 0.1 & 0.4 & 0.6 & 2.4 & 2.3 \\
Number of Foreign Faculty & 1108 & 1373 & 2745 & 4957 & 6064 \\
Percentage of Total Faculty & 1.9 & 2.4 & 4.1 & 6.4 & 6.8 \\
\hline
\end{tabular}

Source: Korean Ministry of Education, Statistical Yearbook of Education, 2014

The gap between outbound and inbound student movement is a continuing problem. Korea is the largest 'exporter' of higher education students in the OECD, as a proportion of population. In 2014, there were 219,543 Korean students abroad, albeit down from 289,288 in 2011 (MOE, 2014). This is an aggregate figure that includes exchange students and language students as well as higher education degree enrolments. However, it is a dramatic figure when considered against the total number of Korean HEI enrolments in 2014 being 3,668,747. Although economic capacity of households has decreased, Korean postgraduate students still prefer to pursue a doctoral degree abroad, particularly in the US, after completing a Masters degree in Korea. Korean graduate schools still find it hard to 
recruit the best doctoral students (Choi, 2014). Also, many strong students choose to study English language in English speaking countries as a step towards university enrolment in that country.

The number of foreign faculty has also increased only modestly, and from a very low base. Media commentary regularly complains that these low numbers result from unattractive conditions for foreign staff and difficulty with the 'top down' organizational culture of Korean HEIs. As shown in Table 4, there were 1,108 international faculty in 1995 representing $1.9 \%$ of total faculty. In 2014, these figures rose to 6,064 or $6.8 \%$ of total faculty (MOE, 2014). However, these figures are distorted as native speaker language instructors, particularly conversational English teachers, are regularly misreported by HEIs as academic faculty in order to reflect government hiring targets. The WCU Project, though, did have a qualitative impact and by 2011, 342 internationally prominent scholars had been recruited by individual universities funded by the program, including nine Nobel laureates (Byun, Jon \& Kim, 2013)..

\subsection{Indicator 5: Quality of EMI Programs}

EMI is a widely used internationalization policy in non-English speaking countries, most effectively in Europe. In the Korean case, EMI is a seemingly rational policy aimed at declining enrolments by stemming the flow of domestic students to English speaking countries and by increasing the number of international students coming to Korea to study programs delivered in English. However, a recent study found that the vast majority of foreign students in Korea, who are Chinese, do not perceive EMI courses very favorably. The availability of EMI and even financial aid were not major draws for East Asians compared to those students from North America and Europe (Jon, Kim \& Byun, 2014). Nevertheless, EMI is increasing and is seen by institutions as a tool for internationalizing both teaching and research. It is strongly supported by the mainstream Korean media (Pillar \& Cho, 2013).

In 2003, Korea University was the first of the 'SKY' universities (Note 11) to deliver lectures in English. Byun et al. (2011) reviewed the effectiveness of EMI at Korea University in a study focused on implementation. They found that, although the EMI policy seemed to have produced, in general, positive outcomes, there was considerable misgiving among some groups. The compulsory enforcement of EMI without regard to students' or instructors' language proficiency, the lack of a support system and appropriate instructors to conduct EMI classes, and the unilateral implementation of EMI across academic disciplines all brought about a number of side effects (Byun et al., 2011). In a separate study in another university, Kym \& Kym (2014) found that "students' overall level of satisfaction and ability to comprehend were significantly different according to the instructor's native language (native English speaker or non-native English speaker), background knowledge, and study-abroad experiences" (p. 35).

In a dramatic move in 2013, the Korean Advanced Institute of Science and Technology (KAIST) unilaterally introduced a 100\% English language policy for all teaching which sparked a fierce debate over the 'Americanization' of higher education, criticism from faculty groups and was blamed for several student suicides. Macdonald argues that approaches to internationalization in Korea have often entailed a change in language policy and that "English-medium instruction (EMI) at universities is seen as an integral part of Korean higher education's international competitiveness" (2009, p. 52). However, EMI is an unpopular policy among large groups of students and staff and is increasing the divide between elite universities and other institutions. There are also wider reservations within Korea about the quality of English language education generally, and the performance of both students and faculty in programs delivered in English. Criticism by prominent educationalists of the Korean approach to memorization and rote learning for second language acquisition is common (Murray, 2014).

\section{Conclusion and way forward}

Consecutive Korean governments have used deregulation as a key strategy to promote the international dimensions of its higher education sector during the 1980s and 1990s. Private resources shifted into the sector and expanded the number of HEIs, inadvertently colliding with a declining birthrate and creating overcapacity. This, in turn, forced the government to implement a schedule of closures and mergers of the worst performing, mostly private, regional HEIs. Finally, there is a widespread view within Korean HEIs that the overall quality of higher education has suffered from the rapid expansion (OECD, 2009). Instead of a bright international future for higher education that was embedded in the segyehwa vision, Korea is struggling to internationalize its higher education system while managing the structural pressures of: a declining school age population; an oversupply of graduates; and unease among many about the quality of the system. This article recommends that future policy development and implementation should focus on three broad areas: 1) strengthening quality assurance; 2) increasing engagement with international bodies and networks; and 3) enforcing regulatory compliance.

Focus area 1): strengthening quality assurance. The survival of many Korean HEIs is dependent on attracting more 
international students and stemming the flow of Korean students abroad. International perceptions of quality are crucial to achieving this and currently, the quality assurance system in comparable countries is perceived as being more rigorous and transparent. The Korean government openly admits that ensuring the quality of the higher education sector and raising competitiveness is a long standing issue and until the introduction of the current comprehensive quality regime, "there was still no formal legal basis for the evaluation of HEIs" (KEDI, 2011). The current role of the KCUE is problematic. It was established as the key advocate for private universities, yet implements a quality assurance evaluation system for its own members. Deregulation has reinforced this conflict of interest, as has the collapse in student numbers and the culturally powerful position of higher education in Korean society. Disclosure of program and institutional evaluation results is a recent and welcome new arrangement, and needs to be further developed.

Focus area 2): increasing engagement with international bodies and networks. Korea has been slow to engage meaningfully with international bodies. The key international quality body, the International Network for Quality Assurance Agencies in Higher Education (INQAAHE), actively works with member agencies in policy development and implementation. It also promotes regional quality networks. The KCUE and KCCE did not join the Asia Pacific Quality Network (APQN) until 2010. These international organizations provide experience of institutional level quality instruments and international student and staff management systems with which Korea is still struggling. The government now openly states that the higher education sector must expand its ties with international organizations "if Korea is to further its evaluation and quality assurance systems" (KEDI, 2011, p. 280). International engagement in the sector must go beyond the current, largely rhetorical memoranda arrangements with overseas universities that have few outcomes.

Focus area 3): enforcing regulatory compliance. The failure of governance in this case study has been the failure to ensure regulatory compliance. Deregulation neglected to incorporate adequate reporting and accountability at the institutional level to ensure continuous monitoring of policy implementation. Korean HEIs are still reluctant participants in the reporting mechanisms around the new quality agenda. However, it would be disadvantageous for Korea to return to structures of central regulation that reinforce a historically conservative organizational culture. There is strong evidence in many national cases that institutional autonomy is essential to create a diverse system of HEIs that can engage with the increasing mobility in higher education. The current restructuring process in Korea is difficult and implicitly involves financial punishments and rewards. Closures and mergers of HEIs will continue to produce political conflict. The effectiveness of evaluation and reporting processes is yet to be tested under the new quality regime. This will be crucial to ensure that institutions function strategically, pursue diverse missions, and yet comply with quality frameworks.

\section{References}

Ahn, A.T. (2012, 4 May, 2012). Korea to attract 200,000 foreign students by 2020. The Korea Times. Retrieved 31 March, 2015 from http://www.koreatimes.co.kr/www/news/nation/2012/05/113_110310.html

Altbach, P. G. (2004). Globalisation and the university: Myths and realities in an unequal world. Tertiary Education and Management. 10 (1): 3-25. http://dx.doi.org/10.1023/B:TEAM.0000012239.55136.4b

Altbach, P. G. \& Salmi, J. (Eds). (2011). The road to academic excellence: The making of world-class research universities. Washington DC: The World Bank. http://dx.doi.org/10.1596/978-0-8213-8805-1

Altbach, P. G., \& Knight, J. (2007). The internationalization of higher education: Motivations and realities. Journal of Studies in International Education. 11(3/4): 290-305. http://dx.doi.org/10.1177/1028315307303542

Bahk, E. (2013, 18 December). Cuts in university student quotas unavoidable. The Korea Times. Retrieved 2 October, 2014, from http://koreatimes.co.kr/www/news/nation/2013/12/113_148211.html

Bauman, C. (2014). Universities as portals of globalisation: Crossroads of internationalisation and area studies. Working Paper Series of the Center for Area Studies No. 4. Leipzig: Leipziger Universitatsverlag GmbH. Retrieved 11 September, 2014 from http://www.academia.edu/8078903/Universities_as_Portals_of_Globalization_Crossroads_of_Internationalizati on_and_Area_Studies_-_Introduction

Byun, K. (2008). New public management in Korean higher education: Is it reality or another fad. Asia Pacific Education Review, 9(2), 190-205. http://dx.doi.org/10.1007/BF03026499

Byun, K., Chu, H., Kim, M., Park, I., Kim, S., \& Jun, J. (2011). English-medium teaching in Korean higher education: Policy debates and reality. Higher Education. 62(4), 431-449. 
http://dx.doi.org/10.1007/s10734-010-9397-4

Byun, K., \& Kim, M. (2011). Shifting patterns of the government's policies for the internationalization of Korean higher education. Journal of Studies in International Education. 15(5), 467-486. http://dx.doi.org/10.1177/1028315310375307

Byun, K., Jon, J. E., \& Kim, D. (2013). Quest for building world class universities in South Korea: Outcomes and consequences. Higher Education, 65(5), 645-659. http://dx.doi.org/10.1007/s10734-012-9568-6

Chang, S.J. (2007). A cultural and philosophical perspective on Korea's education reform: A critical way to maintain Korea's economic momentum. Korea Economic Institute of America Academic Paper Series. 3(2), 1-10. Retrieved 31 March, 2015 from http://keia.org/sites/default/files/publications/Chang.pdf

Cho, H. Y., \& Palmer J. D. (2013). Stakeholders' views of South Korea's higher education internationalization policy. Higher Education 65(3), 291-308. http://dx.doi.org/10.1007/s10734-012-9544-1

Choi. S. (2013). CAMPUS Asia and its implications for university cooperation in Asia and EU: The Korean perspective. In Marx, A., Wouters, J., Moon, W., Rhee, Y., Park, S., \& Burnay, M. (Eds). EU-Korea relations in a changing world. Leuven: Leuven Centre for Global Governance Studies. Retrieved 5 September, 2014, from http://ghum.kuleuven.be/ggs

Findlay. C., \& Tierney. W. G. (Eds). (2010). Globalisation and tertiary education in the Asia-Pacific: the changing nature of a dynamic market. Singapore: World Scientific Publishing. http://dx.doi.org/10.1080/00071005.2011.584665

Jon, J., \& Lee, J. L, \& Byun, K. (2014) The emergence of a regional hub: Comparing international student choices and experiences in South Korea. Higher Education, 67(5), 691-710. http://dx.doi.org/10.1007/s10734-013-9674-0

Kehm, B., \& Teichler, U. (2007).Research on internationalisation in higher education. Journal of Studies in International Education. 11(3/4), 260-273. http://dx.doi.org/10.1177/1028315307303534

Kim, S., \& Lee, J. H. (2006). Changing facets of Korean higher education: market competition and the role of the state. Higher Education. 52 (3): 557-587. http://dx.doi.org/10.1007/s10734-005-1044-0

Kim, T., (2008). Higher education reforms in South Korea: Public-private problems in internationalizing and incorporating universities. Policy Futures in Education. 6(5), 558-568. http://dx.doi.org/10.2304/pfie.2008.6.5.558

Kim, Y. C. (2008). Universalization of tertiary education: Understanding Korean education policy. Vol 2. Seoul: Korean Educational Development Institute. Retrieved 19 September, 2014, from http://hedbib.iau-aiu.net/pdf/KEDI_Universalization_of_Teritary_Education.pdf

Knight, J. (2004). Internationalisation remodelled: definitions, approaches and rationales. Journal of Studies in International Education, 8 (1), 5-31. http://dx.doi.org/10.1177/1028315303260832

Knight, J. (1997). Internationalization of higher education: a conceptual framework. In J. Knight, \& H. de Wit (Eds). Internationalisation of higher education in Asia Pacific countries (pp. 5-19). Amsterdam: European Association of International Education (EAIE).

Korea Joongang Daily. (2014, 29 September). International investors flock to high-tech IFEZ. Retrieved 3 November, 2014, from http://koreajoongangdaily.joins.com/news/article/article.aspx?aid=2995423

Korean Council for University Education. (2014). Korean Council for University Education. Seoul: KCUE. Retrieved 30 March, 2015 from http://english.kcue.or.kr/img/2013_KCUE_Brochure_English_150202.pdf

Korean Council for University College Education. (2009). College Education in Korea 2009-2010. Seoul: KCCE. Retrieved 30 March, 2015 from http://www.kcce.or.kr/guide/viewer/English.pdf

Korean Education Development Institute. (2011). Australia - Republic of Korea Quality Assurance in Higher Education. (2012). Seoul: Korean Education Development Institute (KEDI).

Korean Education Development Institute. (2012). Daehakeui Waegukin Yuhaksaeng Guanri mit Jiwon Chaejae Ganghwa Bangan Yeongu. Seoul: Korean Education Development Institute (KEDI).

Korean Ministry of Education. (2014). Statistical Yearbook of Education, 2014. Seoul: Korean Education Statistics Service. Retrieved 30 March, 2015 from http://kess.kedi.re.kr/eng/index 
Kwon, K. (2012). Government policy and internationalization of universities: The case of international student mobility in Korea. Journal of Contemporary Eastern Asia, 12(1), 35-47. http://dx.doi.org/10.17477/jcea.2013.12.1.035

Kym, I., and Kym, M. (2014). Students' perceptions of EMI in higher education in Korea. The Journal of Asia TEFL, 11(2), 35-61. Retrieved 31 March, 2015 from http://www.asiatefl.org/main/main.php?inx_journals=40\&inx_contents $=49 \&$ main $=6 \&$ sub $=5 \&$ submode $=3 \&$ s_tit le=Students_Perceptions_of_EMI_in_Higher_Education_in_Korea

Macdonald, K. (2009). Korean higher education striving for competitiveness: The role of English-medium instruction and micro-level policy makers. TESOL Review, 51-76. Retrieved 31 March, 2015 from http://www.tesolreview.org/down/3.\%20Kara\%20McDonald.pdf

Mo, J., \& B. R. Weingast. (2013). Korean political and economic development: Crisis, security and institutional rebalancing. Cambridge: Harvard University Asia Center.

Murray, J. D. (2014, 16 November). Failure or success in English education. The Korea Herald. p. 8.

Organisation for Economic Cooperation and Development. (2009). OECD reviews of tertiary education: Korea. Paris: OECD. Retrieved 16 September, 2014, from http://www.oecd.org/edu/skills-beyond-school/thematicreviewoftertiaryeducation-countryreviews.htm

Organisation for Economic Cooperation and Development. (2014). Education at a glance: OECD indicators. Retrieved 19 September, 2014 from http://www.oecd.org/edu/Education-at-a-Glance-2014.pdf

Organisation for Economic Cooperation and Development. (2014). Lessons from PISA for Korea: Strong performers and successful reformers in education. Paris: OECD.

Pillar I., \& Cho J. (2013). Neoliberalism as language policy. Language and Society, 42(1), 23-44. http://dx.doi.org/10.1017/S0047404512000887

Salmi, J. (2009). The challenge of establishing world-class universities. Washington DC: The World Bank. Retrieved 21 September, 2014, from http://siteresources.worldbank.org/EDUCATION/Resources/278200-1099079877269/547664-1099079956815/ 547670-1237305262556/WCU.pdf

Sharma, Y. (2011, 21 August). 'South Korea: Difficult decisions face branch campuses'. University World News. Issue No 185. Retrieved 22 September, 2014, from http://www.universityworldnews.com/article.php?story=20110819173557274

Shin, J.C. (2009). Building world-class research university: The Brain Korea 21 Project. Higher Education. 58(5), 669-688. http://dx.doi.org/10.1007/s10734-009-9219-8

Shin, J.C. (2015a). Mass higher education and its challenges for rapidly growing East Asian higher education. In Shin, J.C., Postiglione, G. A., \& Huang, F. (Eds). Mass higher education development in East Asia: Strategy, quality and challenges (pp1-26). Cham: Springer. http://dx.doi.org/10.1007/978-3-319-12673-9_1

Shin, J.C. (2015b). Higher Education Development in Korea: Accomplishments and Challenges. In Shin, J.C., Postiglione, G. A., \& Huang, F. (Eds). Mass higher education development in East Asia: Strategy, quality and challenges (pp43-61). Cham: Springer. http://dx.doi.org/10.1007/978-3-319-12673-9_3

Tai, C. (2014, 9 March). Plans for dramatic university cutbacks causes disquiet. World University News. Retrieved 10 October, 2014, from http://www.universityworldnews.com/article.php?story=20140309162215189

The Chosun Ilbo. (2014, 17 September). 6 Korean universities in global top 200. Retrieved 10 November, 2014 from http://english.chosun.com/site/data/html_dir/2014/09/16/2014091600929.html

Times Higher Education. (2014). The Times higher education world university rankings 2014-2015. Retrieved 10 October, 2014, from http://www.timeshighereducation.co.uk/world-university-rankings/2014-15/world-ranking

Universitas 21. (2014). U21 ranking of national higher education systems 2014. Melbourne: Melbourne Institute of Applied Economic and Social Research. Retrieved 31 March, 2015 from http://www.universitas21.com/article/projects/details/152/u21-ranking-of-national-higher-education-systems

Van der Wende, M. (2001). Internationalisation policies: about new trends and contrasting paradigms. Higher Education Policy. 14(3), 249-259. http://dx.doi.org/10.1016/S0952-8733(01)00018-6

World Trade Organisation. (2001). GATS - Facts and Fiction. Geneva: World Trade Organisation. Retrieved 11 
October, $2014 \mathrm{http}: / /$ www.wto.org/english/tratop_e/serv_e/gats_factfiction_e.htm

World Economic Forum. (2014). The Global Competitiveness Report 2014-2015. Geneva: WEF. Retrieved 31 March, 2015 from http://www3.weforum.org/docs/WEF_GlobalCompetitivenessReport_2014-15.pdf

Yim, H. (2002). Cultural identity and cultural policy in South Korea, The International Journal of Cultural Policy, 8(1), 37-48. http://dx.doi.org/10.1080/10286630290032422

Yun, Y. (2013, 28 September). Open up and globalize university education. The Korea Times. Retrieved 20 March, 2015 from http://www.koreatimes.co.kr/www/common/printpreview.asp?categoryCode=181\&newsIdx=95650

\section{Notes}

Note 1. In this article, 'higher education' refers to activity that occurs in "universities and other tertiary institutions that award degrees and advanced research qualification" (OECD, 2009, p. 16).

Note 2. In this case study, the term higher education institution (HEI) refers to both four year institutions and two year junior colleges and technical colleges. This includes the 203 members of the Korean Council for University Education (KCUE), which this article also refers to as universities. KCUE institutions are graduate schools and four year degree institutions including public, private, industrial, cyber and education universities (KCUE, 2014). HEIs, also called junior colleges, are the 146 post-secondary and vocational training institutions that are members of the Korean Council for University College Education (KCCE, 2009).

Note 3. Segyehwa translates into English as both globalization and internationalization. It also evokes the need for national unity in order to survive and prosper in the international environment.

Note 4. Philip G. Altbach, Jane Knight, Peter Scott, Ulrich Teichler, Marijk van der Wende and Hans de Wit are the prominent early scholars of the internationalization of higher education. Ivar Bleiklie, Ase Gornitzka and Barbara M. Kehm are also important contributors (Kehm \& Teichler, 2007). Their research reflects European perspectives on policy making and has been closely linked to national policy debates in many countries. Research in the United States has a stronger focus on issues at the institutional level such as curriculum, teaching practices and learning outcomes. There is a growing body of research in East Asia on both national policies and institutional activity.

Note 5. For developed countries with robust higher education systems, the likelihood of being negatively affected by foreign providers is slim. However, for smaller and developing countries with high unmet demand for access to higher education and with less mature academic systems, GATS could result in considerable external impact (Altbach, 2004).

Note 6. This article uses the OECD standard that 'foreign' students and faculty are not Korean citizens. While the term 'foreign' has a somewhat pejorative connotation in many countries, in East Asia government documents and public discourse uses the term without negative intention.

Note 7. For an excellent recent analysis of Korea's post-World War Two development see Mo, J., \& B. R. Weingast. (2013). Korean political and economic development: crisis, security and institutional rebalancing. Cambridge: Harvard University Asia Center.

Note 8. The full title of this important document was The First Educational Reform Plans for the Establishment of the New Educational System Initiated Internationalisation and Informationalization. It was the first of four reports between 1995 and 1997 that details the measures approved by the PCER (Kim, Y. C., 2008).

Note 9. The main education agency of the Korean government has had several name changes and restructures during the period discussed in this article. Under the Kim Young Sam administration, the agency was called the Ministry of Education (MOE). In 2001, Kim Dae Jung added Human Resource Development (MOEHRD). In 2008, Lee Myung Bak restructured the agency into the Ministry of Education, Science and Technology (MEST). In March, 2013, under Park Geun Hye, the agency reverted to the title MOE. The Korean Educational Education Institute (KEDI) is a powerful policy agency within the MOE.

Note 10. The KCUE was originally formed as an industry association in 1982 to challenge the government's strong central control and regulation of higher education policy. However, it not only represents universities (membership is compulsory), but also acts as a regulator and is responsible for quality evaluations.

Note 11. The 'top three' universities: Seoul National University; Korea University; and Yonsei University have been referred to as the 'SKY' universities for several decades. 